\title{
CONTINUED GIZZARD SHAD (DOROSOMA CEPEDIANUM) RANGE EXPANSION IN THE COLORADO RIVER BASIN
}

\author{
P. Aaron Webber ${ }^{1,2}$ and M. Tildon Jones ${ }^{1}$
}

\begin{abstract}
Aвstract.-Gizzard shad (Dorosoma cepedianum) was introduced to the Colorado River basin in 1996 as a result of unintentional stocking. It then rapidly spread into lakes and rivers in both the upper and lower Colorado River basins. We captured adult gizzard shad in the Yampa and White rivers in Colorado in 2012 during boat electrofishing surveys not specifically targeting gizzard shad. These captures document the range expansion of gizzard shad into these Green River tributaries. We also collected larval and young-of-year gizzard shad during seining surveys in backwaters of the middle Green River in 2012, thereby confirming that this species successfully reproduces and recruits in the Green River. The introduction and expansion of gizzard shad has the potential to negatively affect sport fisheries and native fish communities in the Colorado River basin.
\end{abstract}

Resumen. - Arenque de molleja (Dorosoma cepedianum) fue introducido en la cuenca del Río Colorado en 1996 no intencionalmente como resultado de un cultivo de peces, y se extendió rapidamente en los lagos y ríos tanto en la parte superior e inferior de las cuencas del Río Colorado. Capturamos adultos del arenque de molleja en los ríos Yampa y White en Colorado en 2012 durante encuestas de barco electropesca no especificamente dirigidos a los arenque de molleja. Estas capturas documentan la expansión del rango del arenque de molleja en los afluentes del Río Green. Tambien recogimos larvas y juveniles del arenque de molleja en 2012 en media del Río Green, lo que confirma que esta especie se reproduce con exito y recluta en el Río Green. La introducción y expansión del arenque de molleja tiene el potencial de afectar negativamente a la pesca deportiva y las comunidades de peces nativos en la cuenca del Río Colorado.

Gizzard shad (Dorosoma cepedianum) is a clupeid whose native range in North America extends from northeastern Mexico to Quebec, Canada, and from the Atlantic Ocean to as far west as North Dakota (Etnier and Starnes 1993). In its native range, gizzard shad tends to thrive in many habitats, including slow-gradient, large river systems (Minckley and Marsh 2009) similar to mainstem river habitats found in the Colorado River basin. Introduction of this species is potentially detrimental to sport fisheries and native fish communities. Gizzard shad is known to dominate fish communities (Noble 1981), alter entire food webs (DeVries and Stein 1992), and exploit food resources in floodplain habitats (Zeug et al. 2009). Specifically, it can reproduce quickly (Miller 1960, Pierce 1977) and compete with other fishes for zooplankton during larval stages (DeVries and Stein 1992), but it is capable of switching to phytoplankton or detritus at juvenile and adult stages (Miller 1960, Bodola 1966, Pierce 1977, Sublette et al. 1990). Gizzard shad grows quickly (Bodola 1966, Vatland and Budy 2007) and exceeds the gape limitation of most preda- tory species by the end of its first year (Adams and DeAngelis 1987, Johnson et al. 1988).

Gizzard shad is thought to have been introduced accidentally into the San Juan River basin circa 1996 as an unintended hitchhiker in a load of largemouth bass stocked into Morgan Lake, New Mexico (Mueller and Brooks 2004). It spread to the lower San Juan River by 2000 (Mueller and Brooks 2004) and became established throughout Lake Powell, Utah and Arizona, by 2003 (Vatland and Budy 2007). From Lake Powell, gizzard shad moved up the Colorado and Green rivers in Utah and Colorado, reaching the Green River near Ouray National Wildlife Refuge, Utah, by 2005 (Christopherson et al. 2005) and the lowermost Gunnison River and the Colorado River in the Grand Valley by 2006 (McAda and Burdick 2006). A single gizzard shad (122 $\mathrm{mm}$ total length) was captured in 2008 in the Dirty Devil River (Breidinger and Birdsey 2008). The species exhibited further progress upstream when one adult was collected in the Green River near the Yampa River confluence in Dinosaur National Monument by 2007

\footnotetext{
${ }^{1}$ Colorado River Fishery Project, U.S. Fish and Wildlife Service, 1380 S 2350 W, Vernal, UT 84078

${ }^{2}$ E-mail: aaron_webber@fws.gov
} 


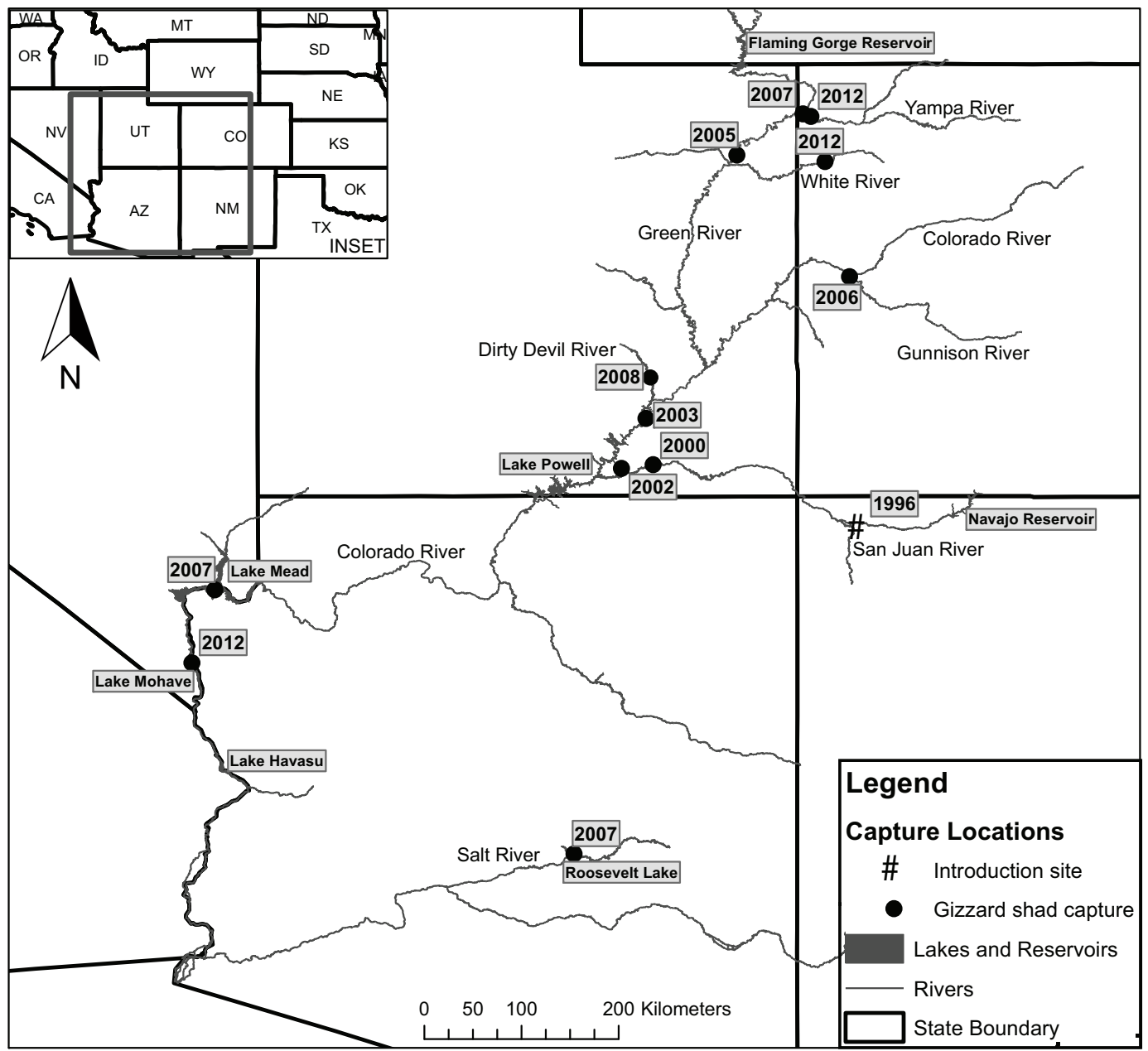

Fig. 1. Map showing dates and locations of the invasion and spread of the nonnative gizzard shad (Dorosoma cepedianum) to the Colorado River basin from 1996-2012.

(Finney and Fuller 2008). In the lower Colorado River basin, gizzard shad was first documented in Lake Roosevelt in central Arizona in 2007 , and by 2008 , it was the second most abundant fish in netting surveys (Minckley and Marsh 2009). Gizzard shad invaded Lake Mead in 2007 and is now established there (Jon Sjoberg, Nevada Department of Wildlife, personal communication). The most recent range expansion was the capture of 3 gizzard shad (range 220-270 $\mathrm{mm}$ total length) in Lake Mohave in November 2012 (Eric Loomis, U.S. Bureau of Reclamation, personal communication). The presence of this species in Lake Roosevelt prior to detection in reservoirs in the intervening reaches of river raises the pos- sibility of a second introduction in the Gila River basin, although we are not aware of records that confirm this. Clearly, gizzard shad has successfully spread and established itself throughout the Colorado River basin since its introduction. We now add 2 more rivers to the list of areas invaded by gizzard shad in the Colorado River basin (Fig. 1).

We captured gizzard shad for the first time in the White and Yampa rivers (tributaries to the Green River) in 2012. Two adult gizzard shad were electrofished in the White River, with the most upstream individual $(430 \mathrm{~mm}$ total length) caught near river kilometer 154 , between Kenney Reservoir and Rangely, Colorado. One adult gizzard shad $(446 \mathrm{~mm}$ total 
length) was sampled in the Yampa River at approximately river kilometer 11 . In addition to this range expansion, we collected larval, young-of-year, and adult gizzard shad on 11 July 2012 and again on 1 August 2012 while seining in Green River backwaters between river kilometers 413 and 414 . The larval and juvenile samples have been verified and catalogued at the Colorado State University Larval Fish Laboratory, Fort Collins, Colorado (cata$\log$ numbers 121480-121484). This finding confirms successful reproduction and recruitment in the middle Green River, first detected in 2006 with the collection of young-of-year in this reach (Goddard et al. 2006). Although gizzard shad pose a threat to both sport fisheries and native fish communities within the Colorado River basin, there are no formal research projects aimed specifically at removing gizzard shad in the Colorado River basin; all gizzard shad reported in this note were captured during seining, netting, and electrofishing projects for monitoring other fish species.

We thank the Upper Colorado River Endangered Fish Recovery Program for funding the projects from which these data were gathered.

\section{Literature Cited}

Adams, S.M., AND D.L. DeAngelis. 1987. Indirect effects of early bass-shad interactions on predator population structure and food web dynamics. Pages 103117 in W.C. Kerfoot and A. Sih, editors, Predation: direct and indirect impacts on aquatic communities. University Press of New England, Hanover, NH

Bodola, A. 1966. Life history of the gizzard shad, Dorosoma cepediamum (LeSueur), in western Lake Erie. U.S. Fish and Wildlife Service Fishery Bulletin 65: 391-425.

Breidinger, K., AND P. BiRdsey. 2008. Three species conservation in Utah's southeast region during 2008 Pages 3-1 to 3-24 in S.L. Jones, editor, Three species statewide monitoring summary, 2008. Publication number 09-27, Utah Division of Wildlife Resources, Salt Lake City, UT.

Christopherson, K., P. Badame, and M.H. Fuller. 2005. Smallmouth bass control in the middle Green River. Annual report to the Upper Colorado River Endangered Fish Recovery Program, project 123.

DeVries, D.R., and R.A. Stein. 1992. Complex interactions between fish and zooplankton: quantifying the role of an open-water planktivore. Canadian Journal of Fisheries and Aquatic Sciences 49:1216-1227.

Etnier, D.A., and W.E. Starnes. 1993. The fishes of Tennessee. University of Tennessee Press, Knoxville. TN.

Finney, S.T., AND M.H. Fuller. 2008. Gizzard shad (Dorosoma cepedianum) expansion and reproduction in the Upper Colorado River Basin. Western North American Naturalist 68:524-525.

Goddard, P., P. Badame, T. Hedrick, L. Monroe, and K. Bestgen. 2006. Young-of-the-year Colorado pikeminnow monitoring. Annual report to the Upper Colorado River Endangered Fish Recovery Program, project 138 .

Johnson, B.M., R.A. Stein, and R.F. Carline. 1988. Use of a quadrat rotenone technique and bioenergetics modeling to evaluate prey availability to stocked piscivores. Transactions of the American Fisheries Society $117: 127-141$.

McAda, C., AND B.D. Burdick. 2006. Removal of smallmouth bass in the upper Colorado River between Price-Stubb Dam near Palisade, Colorado, and Westwater, Utah. Annual report to the Upper Colorado River Endangered Fish Recovery Program, project 126a.

Miller, R.R. 1960. Systematics and biology of the gizzard shad (Dorosoma cepedianum) and related fishes. U.S. Fish and Wildlife Service Fishery Bulletin 173: 371-392.

MinCKLEY, W.L., AND P.C. Marsh. 2009. Inland fishes of the greater southwest: chronicle of a vanishing biota. University of Arizona Press, Tucson, AZ.

Mueller, G.A., AND J.L. Brooks. 2004. Collection of an adult gizzard shad (Dorosoma cepedianum) from the San Juan River, Utah. Western North American Naturalist 64:135-136.

Noble, R.L. 1981. Management of forage fishes in impoundments of the southern United States. Transactions of the American Fisheries Society 110:738-750.

Pierce, R.J. 1977. Life history and ecological energetics of the gizzard shad (Dorosoma cepedianum) in Acton Lake, Ohio. Doctoral dissertation, Miami University, Oxford, $\mathrm{OH}$.

Sublette, J.E., M.D Hatch, and M. Sublette. 1990. The fishes of New Mexico. University of New Mexico Press, Albuquerque, NM.

Vatland, S., ANd P. Budy. 2007. Predicting the invasion success of an introduced omnivore in a large, heterogeneous reservoir. Canadian Journal of Fisheries and Aquatic Sciences 64:1329-1345.

Zeug, S.C., D. Peretti, and K.O. Winemiller. 2009. Movement into floodplain habitats by gizzard shad (Dorosoma cepedianum) revealed by dietary and stable isotope analyses. Environmental Biology of Fishes 84:307-314

Received 5 September 2012 Accepted 13 February 2013 